\author{
Asian Journal of \\ Medical and Biological Research \\ ISSN 2411-4472 (Print) 2412-5571 (Online) \\ www.ebupress.com/journal/ajmbr
}

\title{
Article \\ Study on prevalence of bovine diseases at sadar upazila in dinajpur district of Bangladesh
}

\author{
Moktar Omar Mohammed ${ }^{1}$, Md. Shajedur Rahman ${ }^{2 *}$, Md. Fazlul Hoque ${ }^{3}$, Nazmi Ara Rumi ${ }^{4}$ and Osman Hassan \\ Afrah $^{5}$ \\ ${ }^{1}$ Faculty of Veterinary Medicine, University of Somalia, Mogadisho- Somalia \\ ${ }^{2}$ Department of Medicine, Surgery \& Obstetrics, Hajee Mohammad Danesh Science \& Technology University, \\ Dinajpur, Bangladesh \\ ${ }^{3}$ Department of Medicine, Surgery \& Obstetrics, Hajee Mohammad Danesh Science \& Technology University, \\ Dinajpur, Bangladesh \\ ${ }^{4}$ Department of Microbiology, Hajee Mohammad Danesh Science \& Technology University, Dinajpur, \\ Bangladesh \\ ${ }^{5}$ Benadir Livestock Professional Association, Somalia
}

${ }^{*}$ Corresponding author: Md. Shajedur Rahman, Assistant Professor, Department of Medicine, Surgery and Obstetrics, Hajee Mohammad Danesh Science \& Technology University, Dinajpur, Bangladesh. Phone: +8801716324876; E-mail: Shajedur.medicine@yahoo.com

Received: 04 December 2017/Accepted: 21 December 2017/ Published: 28 December 2017

\begin{abstract}
The study was conducted to investigate the status of cattle diseases with relation to seasonal variation in Dinajpur district of Bangladesh. A total of 11402 clinical cases were registered for the clinical diagnosis and therapeutic purposes at sadar upazila veterinary hospital in Dinajpur district of Bangladesh during the period of March, 2016 to February, 2017. Disease diagnosis was made on the basis of owner's statement, general examination and clinical signs. Diagnosed diseases were categorized as general clinical disorders, parasitic diseases, viral diseases, bacterial diseases, venereal disease, and metabolic disorders. According to study the highest $(64.15 \%)$ prevalence was by parasitic disease followed by bacterial diseases $(10.67 \%)$, viral diseases $(8.97 \%)$, metabolic disease $(7.61 \%)$, and venereal disease $(6.60 \%)$. In respect of seasons, the prevalence of both bacterial diseases and viral diseases were significantly $(\mathrm{p}<0.01)$ higher $(13.88 \%)$ and $(12.10 \%)$ in summer season respectively. Whereas the parasitic diseases were significantly $(p<0.01)$ higher $(68.65 \%)$ in winter season. On the basis of season, it was found that the overall prevalence of diseases was highest in summer season $(47.87 \%)$ followed by rainy season $(30.10 \%)$ and comparatively lower in winter season $(22.03 \%)$.
\end{abstract}

Keywords: prevalence; cattle; diseases; season

\section{Introduction}

Bangladesh is predominantly an agricultural country where livestock sector plays a pivotal role in accelerating the economic growth. Bangladesh has high density of cattle population, it is about 23.12 million and now-a-days dairy farming has great importance in economic sector. However, dairy farming in Bangladesh frequently focus in different constrains. Bovine diseases affect production, cattle health, impacts negatively on profitability and trade, and can decimate years of genetic improvement towards desirable production traits (Boland et al., 2010). Among the different diseases available in this Dinajpur district include Foot and mouth disease (FMD) which is a severe, highly contagious viral disease of livestock with significant economic impact. The disease affects cattle, swine, sheep, goats and other cloven-hoofed ruminants. Furthermore, elephant, and giraffe are susceptible to FMD (Kitching, 2005). Bovine ephemeral fever (BEF) is a non-contagious arthropod-borne disease of cattle and water buffaloes caused by the bovine ephemeral fever virus (Nandi and Negi, 1999). BEF is characterized 
by the sudden onset of fever, stiffness, lameness and depression with a high morbidity and $1 \%$ mortality (Mackerras et al., 1940). Recovery usually occurs within 3 to 4 days of the onset of clinical signs, hence the term "ephemeral" (Uren, 1989). The disease is mostly severe in the more valuable classes of cattle such as bulls, pregnant and lactating cows (Young and Spradbrow, 1990). Babesiosis is caused by intra-erythrocytic protozoan parasites of the genus Babesia which infects a wide range of domestic and wild animals and occasionally man. The disease is distributed world-wide (Bock et al., 2004). Infection of cattle with Anaplasma marginale causes bovine anaplasmosis, a mild to severe hemolytic disease that results in considerable economic losses to both dairy and beef industries. A. marginale undergoes a complex developmental cycle in ticks that begins by infection of gut cells, and transmission to susceptible hosts occurs from salivary glands during feeding (Ge et al., 1996; Kocan, 1986; Kocan et al., 2004). The prevalence of parasitic infection depends on ecology, geographical and climatic condition prevailing in Bangladesh (Hossain et al., 2004). Gastrointestinal nematodes (Haemonchus, Trichostrogylus and Strogylus) cause impaired digestion and also affect the absorption of minerals particularly the Calcium and Phosphorus (Speedy, 1992). Like other diseases, parasitic infection or concurrently occurred infections cause economic losses in terms of mortality, stunted growth, loss of body weight gain, poor quality of skin due to ectoparasitic in particular, decreased milk and meat production (Dewan et al., 1979; Ahmed et al., 1994). Among the trematode infections, two Fasciola species Fasciola hepatica and Fasciola gigantica are involved in both animal and human fascioliasis (Mas et al., 1999) of these only Fasciola gigantic are available in Bangladesh. The major endemic area for Fasciola gigantica is largely tropical region of Africa and many areas of Asia including India, Pakistan, Bangladesh (Shelmon and Barwari, 1978). In Bangladesh the report on fascioliasis are mostly on cattle, sheep, goat and buffalo (Kendall, 1954; Garrels, 1975 and Okiluddin, 1996). As bovine diseases are very much important disease in aspect of Bangladesh, it is not only affect the production performance of animal but also affect the national economy so the present study focuses the prevalence of disease in cattle in sadar upazila of dinajpur district.

\section{Materials and Methods}

\subsection{Study area and study period}

The study was conducted at veterinary hospital at Sadar upazila in Dinajpur district of Bangladesh for a period of one year from March, 2016 to February, 2017. The animals were brought at upazila veterinary hospital for the treatment purposes were examined for the prevalence of bovine diseases in cattle. A total of 11402 cattle population were recorded during the study period. Various types of bovine diseases were registered where bacterial disease, viral and parasitic disease and metabolic and venereal disease were recorded.

\subsection{Procedure of examination of animal}

\subsubsection{General examination}

Body condition score (BCS), behavior, Posture, gait, superficial skin, salivation, nasal discharge, locomotion disturbances were observed by distant visual examination of the patient.

\subsubsection{Physical examination}

Examination of different external parts of the body of each of the animal clinically, attended at hospital were done by using various close observation techniques.

\subsubsection{Clinical examination}

For clinical examination the temperature, pulse and respiratory rate from each of the animal were recorded. The presented clinical findings of various diseases of cattle and the owners complaint in relation to the diseases were also recorded carefully.

\subsection{Prevalence}

Prevalence were calculated as number of cases of disease divided by population at risk and multiple by 100 .

$$
\text { Prevalence rate }(\%)=\frac{\text { No. of cases of disease }}{\text { population at risk }} \times 100
$$

\subsection{Statistical analysis}

The collected data was analyzed by a statistical software namely, SPSS version 22. Associations between explanatory variables season and prevalence were done by chi-square test. In all analysis, $95 \%$ confidence intervals and $\mathrm{p}<0.05$ were set to indicate significance. 
3. Results

\subsection{Prevalence of bovine bacterial diseases}

The overall prevalence of bacterial diseases in cattle were $10.67 \%$ among these the highest prevalence of bacterial diseases $(6.08 \%)$ were found by mastitis followed by anthrax (1.89\%), dermatophilosis (1.29\%) and the lowest prevalence $(0.67 \%)$ by black quarter, followed by hemorrhagic septicemia $(0.75 \%)$ as shown in (Table 1).

Table 1. Prevalence of bovine bacterial diseases.

\begin{tabular}{lllll}
\hline Disease name & No. of animal examined & No. of positive & Percentage (\%) & $\begin{array}{l}\text { Percentage by } \\
\text { category }(\%)\end{array}$ \\
\hline Anthrax & 11402 & 215 & 1.89 & \\
BQ & 11402 & 76 & 0.67 & 10.67 \\
H.S & 11402 & 86 & 0.75 & \\
Dermatophilosis & 11402 & 147 & 1.29 & 6.08 \\
Mastitis & 11402 & 693 & & \\
\hline
\end{tabular}

\subsection{Prevalence of bovine viral diseases}

The overall prevalence of viral diseases in cattle were 8.97\%. Among viral diseases the highest prevalence (5.79 $\%$ ), were found in Ephemeral fever followed by foot and mouth disease (3.10\%), whereas the lowest prevalence $(0.09 \%)$ were documented in rabies as shown in (Table 2$)$.

Table 2. Prevalence of bovine viral diseases.

\begin{tabular}{lllll}
\hline Disease name & No of animal examined & No of positive & $\begin{array}{l}\text { Percentage } \\
(\boldsymbol{\%})\end{array}$ & $\begin{array}{l}\text { Percentage by } \\
\text { category }(\boldsymbol{\%})\end{array}$ \\
\hline FMD & 11402 & 353 & 3.10 & \\
Rabies & 11402 & 10 & 0.09 & 8.97 \\
E fever & 11402 & 660 & 5.79 & \\
\hline
\end{tabular}

\subsection{Prevalence of bovine parasitic disease}

The overall prevalence of parasitic diseases in cattle were 64.15\%. Parasitic diseases was further subdivided in to protozoa, external parasite and internal parasite. Under protozoa diseases the highest prevalence $(8.55 \%)$ was found in coccidiosis while the lowest $(0.29)$ was found in Theileriosis. In general, the prevalence of protozoa disease was $(2.90 \%)$. Again, under internal diseases the highest prevalence $(12.86 \%)$ was observed roundworm followed by Fascioliasis $(10.28 \%)$ while the lowest prevalence $(7.17 \%)$ was observed in tapeworm. All the prevalence of internal parasite was $(30.31 \%)$. Furthermore, under external parasite diseases, the highest prevalence $(10.77 \%)$ was witnessed in lice whereas the lowest prevalence $(5.46 \%)$ was detected in Tick followed by mite $(6.26 \%)$. Totally the prevalence of external parasite was $(22.49 \%)$ as shown in (Table 3$)$.

Table 3. Prevalence of bovine parasitic disease.

\begin{tabular}{llllll}
\hline Disease name & & $\begin{array}{l}\text { No of animal } \\
\text { examined }\end{array}$ & No of positive & $\begin{array}{l}\text { Percentage } \\
(\%)\end{array}$ & $\begin{array}{l}\text { Category Percentage } \\
(\%)\end{array}$ \\
\hline \multirow{2}{*}{ Protozoa } & Babesiosis & 11402 & 76 & 0.67 & \\
& Theileriosis & 11402 & 33 & 0.29 & 1.84 \\
& Anaplasmosis & 11402 & 210 & 8.55 & \\
Internal & Coccidiosis & 11402 & 975 & 10.28 & 64.15 \\
parasite & Fascioliasis & 11402 & 1172 & 7.17 & \\
& Roundworm & 11402 & 1466 & 5.46 & \\
External & Tapeworm & 11402 & 817 & 10.26 & \\
parasite & Tick & 11402 & 623 & 714 & 17 \\
& Mite & 11402 & 11402 & & \\
\hline
\end{tabular}




\subsection{Prevalence of metabolic and venereal diseases}

The overall prevalence of metabolic and venereal diseases in cattle were $14.22 \%$. The highest prevalence of metabolic and venereal diseases $(7.61 \%)$ was observed from metabolic disease while the lowest $(6.60 \%)$ was found in Venereal disease as shown in (Table 4).

Table 4. Prevalence of metabolic and venereal diseases.

\begin{tabular}{lllll}
\hline Disease name & No of animal examined & No of positive & Percentage (\%) & Category Percentage (\%) \\
\hline Metabolic diseases & 11402 & 868 & 7.61 & \multirow{2}{*}{14.22} \\
Venereal disease diseases & 11402 & 753 & 6.60 & \\
\hline
\end{tabular}

\subsection{Prevalence of bovine viral diseases based on season}

There was significant variation of bovine viral diseases in relation to the season of the year. In summer season the highest prevalence of bovine viral disease $(8.61 \%)$ was observed from Ephemeral fever followed by Foot and mouth disease $(3.38 \%)$ and Rabies $(0.11 \%$ ). Similarly, in rainy season the highest prevalence of bovine viral disease $(7.40 \%)$ was observed from Ephemeral fever followed by Foot and mouth disease $(2.80 \%)$ and Rabies $(0.24 \%)$. Additionally, in winter season, the highest prevalence of bovine viral disease $(3.85 \%)$ was observed from Ephemeral fever followed by Foot and mouth disease $(3.09 \%)$ and Rabies $(0.05 \%)$ shown in (Table 5).

Table 5. Prevalence of bovine viral diseases based on season.

\begin{tabular}{|c|c|c|c|c|c|c|}
\hline \multirow{3}{*}{ Disease Name } & \multicolumn{6}{|c|}{ Season } \\
\hline & \multicolumn{2}{|c|}{ Summer $(n=2753)$} & \multicolumn{2}{|c|}{ Rainy $(n=2540)$} & \multicolumn{2}{|c|}{ Winter(n=6109) } \\
\hline & $\begin{array}{l}\text { No. of animals } \\
\text { affected }\end{array}$ & $\begin{array}{l}\text { Percentage } \\
(\%)\end{array}$ & $\begin{array}{l}\text { No. of animals } \\
\text { affected }\end{array}$ & $\begin{array}{l}\text { Percentage } \\
(\%)\end{array}$ & $\begin{array}{l}\text { No. of animals } \\
\text { affected }\end{array}$ & $\begin{array}{l}\text { Percentage } \\
(\%)\end{array}$ \\
\hline FMD & 93 & 3.38 & 71 & 2.80 & 189 & 3.09 \\
\hline Rabies & 3 & 0.11 & 6 & 0.24 & 3 & 0.05 \\
\hline Ephemeral fever & 237 & 8.61 & 188 & 7.40 & 235 & 3.85 \\
\hline Total & 333 & 12.10 & 265 & 10.43 & 427 & 6.99 \\
\hline \multicolumn{3}{|c|}{ p-value (Chi-square Test) } & \multicolumn{4}{|c|}{$34.224(0.000)$} \\
\hline \multicolumn{3}{|c|}{ Level of Significance } & \multicolumn{4}{|c|}{$* *$} \\
\hline
\end{tabular}

** Highly significant $(\mathrm{p} \leq 1 \%)$

\subsection{Prevalence of bovine bacterial diseases based on season}

In summer season the highest prevalence of bovine bacterial disease $(4.90 \%)$ was detected from Mastitis followed insignificantly by Anthrax (4.65\%) although the lowest $(0.69 \%)$ was found in Black Quarter (BQ) the rest of bacterial disease showed intermediate. Moreover, in rainy season the highest prevalence of bovine bacterial disease $(3.66 \%)$ was identified from Mastitis while the lowest $(0.59 \%)$ was found in Black Quarter (BQ) and the rest were intermediate. Furthermore, in winter season, the highest prevalence of bovine bacterial disease $(7.61 \%$ ) was observed from Mastitis whereas the lowest $(0.29 \%)$ was observed in H.S. the result showed that mastitis was the most prevalence bacterial disease in all the seasons as shown in (Table 6).

Table 6. Prevalence of bovine bacterial diseases based on season.

\begin{tabular}{|c|c|c|c|c|c|c|}
\hline \multirow{3}{*}{ Disease Name } & \multicolumn{6}{|c|}{ Season } \\
\hline & \multicolumn{2}{|c|}{ Summer $(n=2753)$} & \multicolumn{2}{|c|}{ Rainy $(n=2540)$} & \multicolumn{2}{|c|}{ Winter $\mathrm{n}=6109$ ) } \\
\hline & $\begin{array}{l}\text { No. of animals } \\
\text { affected }\end{array}$ & $\begin{array}{l}\text { Percentage } \\
(\%)\end{array}$ & $\begin{array}{l}\text { No. of animals } \\
\text { affected }\end{array}$ & $\begin{array}{l}\text { Percentage } \\
(\%)\end{array}$ & $\begin{array}{l}\text { No. of animals } \\
\text { affected }\end{array}$ & $\begin{array}{l}\text { Percentage } \\
(\%)\end{array}$ \\
\hline Anthrax & 128 & 4.65 & 45 & 1.77 & 42 & 0.69 \\
\hline $\mathrm{BQ}$ & 19 & 0.69 & 15 & 0.59 & 42 & 0.69 \\
\hline H.S & 36 & 1.31 & 32 & 1.26 & 18 & 0.29 \\
\hline Dermatophilosis & 64 & 2.32 & 55 & 2.17 & 28 & 0.46 \\
\hline Mastitis & 135 & 4.90 & 93 & 3.66 & 465 & 7.61 \\
\hline Total & 382 & 13.88 & 240 & 9.45 & 595 & 9.74 \\
\hline \multicolumn{3}{|c|}{ p-value (Chi-square Test) } & \multicolumn{4}{|c|}{$273.317(0.000)$} \\
\hline \multicolumn{3}{|c|}{ Level of Significance } & \multicolumn{4}{|c|}{$* *$} \\
\hline
\end{tabular}

\footnotetext{
** Highly significant $(\mathrm{p} \leq 1 \%)$
} 
3.7. Prevalence of metabolic and venereal diseases based on season

There was significant variation of bovine metabolic and venereal diseases in relation to the season of the year. In summer season the highest prevalence of other bovine disease $(6.10 \%)$ was observed from metabolic disease while the lowest $(5.16 \%)$ was found in Venereal disease. Contrarily in rainy season the highest prevalence of other bovine disease (10.87\%) was observed in metabolic disease. Also in winter season, the highest prevalence of other bovine disease $(7.37 \%)$ was observed in Venereal disease while the lowest $(6.51 \%)$ was detected in metabolic disease shown in (Table 7).

Table 7. Prevalence of metabolic and venereal diseases based on season.

\begin{tabular}{|c|c|c|c|c|c|c|}
\hline \multirow{3}{*}{ Disease Name } & \multicolumn{6}{|c|}{ Season } \\
\hline & \multicolumn{2}{|c|}{ Summer $(n=2753)$} & \multicolumn{2}{|c|}{ Rainy $(n=2540)$} & \multicolumn{2}{|c|}{ Winter(n=6109) } \\
\hline & $\begin{array}{l}\text { No. of animals } \\
\text { affected }\end{array}$ & $\begin{array}{l}\text { Percentage } \\
(\%)\end{array}$ & $\begin{array}{l}\text { No. of animals } \\
\text { affected }\end{array}$ & $\begin{array}{l}\text { Percentage } \\
(\%)\end{array}$ & $\begin{array}{l}\text { No. of animals } \\
\text { affected }\end{array}$ & $\begin{array}{l}\text { Percentage } \\
(\%)\end{array}$ \\
\hline Metabolic disease & 168 & 6.10 & 187 & 7.36 & 398 & 6.51 \\
\hline Venereal disease & 142 & 5.16 & 276 & 10.87 & 450 & 7.37 \\
\hline Total & 310 & 11.26 & 463 & 18.23 & 868 & 14.21 \\
\hline \multicolumn{3}{|c|}{ p-value (Chi-square Test) } & \multicolumn{4}{|c|}{$14.391(0.001)$} \\
\hline \multicolumn{3}{|c|}{ Level of Significance } & \multicolumn{4}{|c|}{$* *$} \\
\hline
\end{tabular}

** Highly significant $(\mathrm{p} \leq 1 \%)$

\subsection{Prevalence of bovine parasitic diseases based on season}

There was significant variation of bovine parasitic diseases in relation to the season of the year. Among parasitic diseases protozoa was subdivided in to subcategory. Under protozoa, in summer season the highest prevalence of bovine parasitic disease (8.43\%) was observed from Coccidiosis and the lowest (1.09\%) was observed from Babesiosis. Similarly, in rainy season the highest prevalence of bovine parasitic disease $(5.75 \%)$ was observed from Coccidiosis while the lowest $(0.43 \%)$ was detected from Babesiosis. Likewise, in winter season, the highest prevalence of bovine parasitic disease $(9.77 \%)$ was observed from Coccidiosis and the lowest $(0.31 \%)$ was observed from Theilariaosis. Under internal parasitic disease, in summer season the highest prevalence of bovine parasitic disease $(14.53 \%)$ was observed from roundworm whereas the lowest $(5.19 \%)$ was observed from tapeworm. In rainy season, the highest prevalence of bovine parasitic disease (13.23\%) was observed from roundworm whereas the lowest $(7.87 \%)$ was observed from Fascioliasis. In winter season, the highest prevalence of bovine parasitic disease (13.88\%) was observed from Fascioliasis whereas the lowest (7.53\%) was observed from tapeworm. Under external parasite diseases, in summer season the highest prevalence of bovine parasitic disease $(9.73 \%)$ was observed from lice whereas the lowest $(5.88 \%)$ was observed from mite. In rainy season, the highest prevalence of bovine parasitic disease $(11.81 \%)$ was observed from lice whereas the lowest $(5.71 \%)$ was observed from mite. In winter season, the highest prevalence of bovine parasitic disease (10.88\%) was observed from lice whereas the lowest (3.73\%) was observed from tick shown in (Table 8).

Table 8. Prevalence of bovine parasitic diseases based on season.

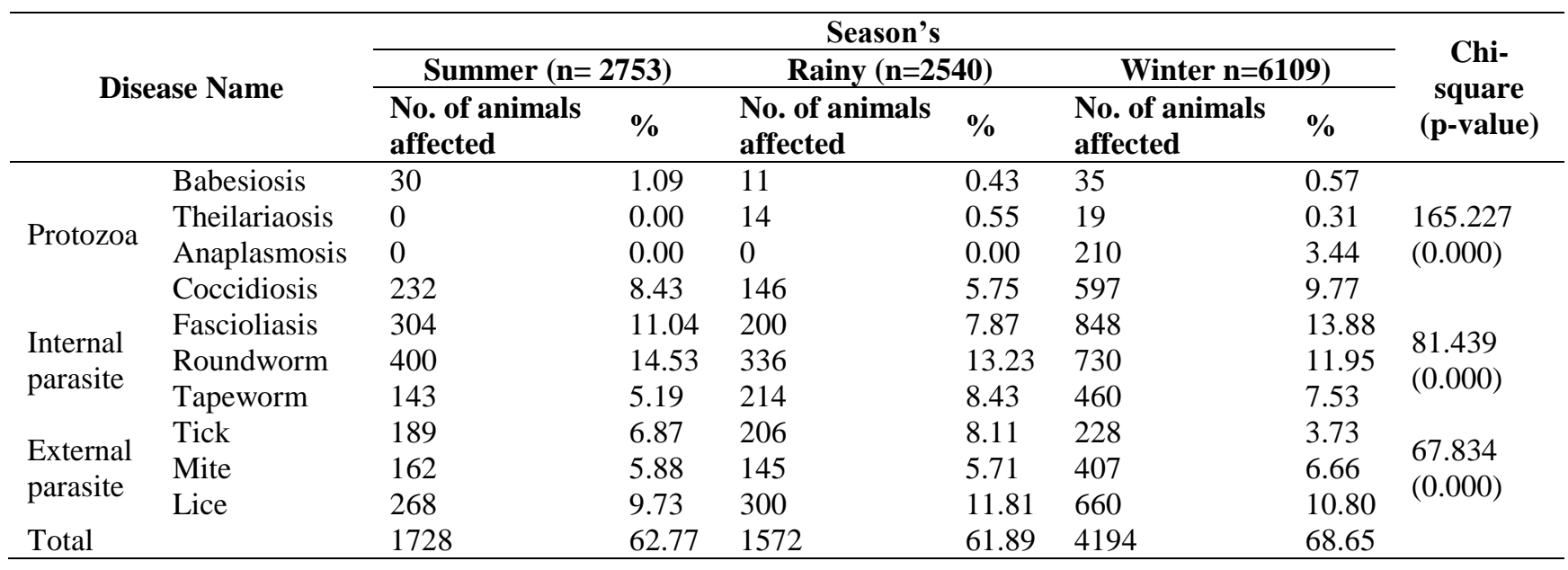

** Highly significant $(\mathrm{p} \leq 1 \%)$ 


\section{Discussion}

\subsection{Prevalence of bovine bacterial diseases}

In this study the overall prevalence of bacterial diseases was $(10.67 \%)$ in which the highest prevalence was noticed in mastitis $(6.08 \%)$ followed by anthrax (1.89\%), Dermatophilosis (1.29\%), hemorrhagic septicemia $(0.75 \%)$ and black quarter (BQ) $(0.67 \%)$. According to the bacterial diseases category the present result was lower than the result of Juli et al. (2015) who reported that the overall prevalence of bacterial diseases in Dinajpur were $15.27 \%$ in which highest prevalence was observed in dermatophilosis $(10.43 \%)$, followed by $(1.76 \%)$, mastitis $(0.73 \%)$, black quarter $(0.59 \%)$. Nath et al. (2010) reported that the prevalence of dermatophilosis $13.55 \%$ which higher than this study. Badruzzaman et al. (2015) reported prevalence of dermatophilosis $0.19 \%$ which significantly different from this result and mastitis was $1.30 \%$ which is lower than this result. Dissimilar results were reported by Karim et al. (2014) who described that prevalence of mastitis and black quarter were $1.1 \%$ and $1.4 \%$ respectively.

\subsection{Prevalence of bovine viral diseases}

The prevalence of FMD in this study was (3.10\%) which was slightly higher than the results of Samad (2001) and Rahman et al. (2012) who reported $1.79 \%, 1.3 \%$ and 2.5\% cases of FMD in cattle respectively. But our results are significantly different from the recent repot of Bangladesh as $4.74 \%$ and $0.27 \%$. Sarker et al. (2011) and Mannan et al. (2009) reported that prevalence of foot and mouth disease (25.07\%) at Rajshahi district and $24.51 \%$ at Meghna upazila of Comilla respectively which was higher than this study. Badruzzaman et al. (2015) conducted a study in Chittagong district of Bangladesh and they found that prevalence of foot and mouth disease and ephemeral fever as $4.74 \%$ and $0.27 \%$.

\subsection{Prevalence of bovine parasitic diseases}

In our present study, the prevalence of ectoparasite of cattle was $22.49 \%$ in which the highest prevalence was recorded in lice $(10.77 \%)$ followed by mite $(6.26 \%)$ and tick $(5.46 \%)$. This result is greater than the findings of Magona et al. (2015) reported that the prevalence of ectoparasitic infection were showed $1.96 \%$ in all clinical cases that was lower than my finding. Rony et al. (2010) conducted a study in Gazipur of Bangladesh, and recorded $68.49 \%, 65.5 \%, 65.4 \%$ and $64.07 \%$ prevalence of tick infestation in cattle, respectively which was higher than my result. Ghosh et al. (2007) reported $80 \%$ cattle affected by ticks in Bangladesh, India and Pakistan. Aulakh (2003) reported the prevalence of babesiosis as 5.94\% in India, which is higher than the results of present study. Subclinical infection of A. marginale in cattle has been reported frequently from many parts of the world as a concurrent infection with other blood parasites like Theileria and Babesia (Afridi et al., 1985). This observation is not consistence with Badruzzaman et al. (2015) who reported that the prevalence of parasitic disease as $30.64 \%$ of which, in summer $12.78 \%$, in rainy $9.79 \%$, winter $8.07 \%$. in Chittagong district and Pallab et al. (2012) who reported $26.79 \%$ parasitic diseases to all clinical cases, of which $10.13 \%$ in cows, $5.22 \%$ in bulls and $11.43 \%$ in calves. Rahman et al. (2012) conducted a study at the Patuakhali Science and Technology University Veterinary Clinic and reported parasitic disease prevalence as $50.4 \%$ which is significantly lower from my study results. Rahman et al. (1972), Das and Hashim (1996) reported that prevalence of maggot-infested wounds $11 \%$, and $2.20 \%$ respectively in cattle from Bangladesh although our observation was slightly different from them.

\subsection{Prevalence of metabolic and venereal diseases}

In this study, the highest prevalence of cattle disease (7.61\%) was found in metabolic disease. Dissimilar findings were reported by Badruzzaman et al. (2015) reported that prevalence of milk fever as $1.26 \%$ which is lower than our observation.

\section{Conclusions}

The present study revealed that various infectious diseases like viral $(8.9 \%)$, bacterial diseases $(10.67 \%)$, parasitic diseases (64.15\%), protozoa, internal parasite and external parasite were found in the cattle population in Dinajpur district of northern Bangladesh. Among the bacterial diseases the highest prevalence was found in Mastitis (6.08\%) however within viral diseases the most prevalence disease was Ephemeral fever (5.79\%). In case of parasitic diseases, the highest prevalence was observed in internal parasite. All bovine diseases, parasitic diseases were highly prevalence $(64.15 \%)$ which counted in this study more than half of the cattle being studied. 
Acknowledgments

This research work was supported by Department of Microbiology, Hajee Mohammad Danesh Science and Technology University, Dinajpur, Bangladesh.

\section{Conflict of interest}

None to declare.

\section{References}

Afridi ZK, Irshad-Ahmad, GZ Khattak, QH Ullah and M Jamil, 1985. Incidence of anaplasmosis, babesiosis and theileriosis in dairy cattle in Peshawar. Sarhad J. Agri., 21: 311-316.

Ahmed JU, M Shamsuddin and MGS Alam, 1994. Effect of seasons on fertility in the zebu cattle of Bangladesh. Bangladesh Journal of Training and Development, 5: 85-93.

Aulakh GS, 2003. Haemato-biochemical and therapeutic studies on haemoparasites in bovines. Department of Veterinary Parasitology, Punjab.Agricultural University, Ludhiana, India.

Badruzzaman ATM, MSI Md. Siddiqui, OF Faruk, NS Lucky, MA Zinnah, FMA Hossain and MM Rahman, 2015. Prevalence of infectious and non-infectious diseases in cattle population in Chittagong district of Bangladesh. International Journal of Biological Research, 3:1- 4.

Boland F, GE Kelly, M Good and SJ More, 2010. Bovine tuberculosis and milk production in infected dairy herds in Ireland. Pre. Vet. Med., 93: 153-161.

Bock R, L Jackson, A de Vos and W Jorgensen, 2004. Babesiosis of cattle, Parasitology, 129 Suppl, S 247-269.

Das BC and MA Hashim, 1996. Studies on surgical affections in calves. Bangladesh Veterinary Journal, 30: 5357.

Dewan ML, MI Hossain, MA Bake and M Uddin, 1979.Observation on the visceral larval migration of Toxocaravitulorum in buffalo calves. Bangladesh Veterinary Journal, 13: 35-37.

Ge NL, KM Kocan, EF Blouin and GL Murphy, 1996: Developmental studies of Anaplasma marginale (Rickettsiales: Anaplasmataceae) in male Dermacentorandersoni (Acari: Ixodidae) infected as adult using nonradioactive in situ hybridization. J. Med. Entomol., 33: 910-920.

Garrels G, 1975. Gastrointestinal parasitic Infestation of cattle in some villages of Dhaka and Tangail Districts in Bangladesh. Bangladesh Veterinary Journal, 9: 9-10.

Ghosh S, GC Bansal, U Seitzer, JS Ahmed, 2007. Status of tick distribution in Bangladesh, India and Pakistan. Para. Res., 2: 207-216.

Hossain MJ, M Amin, M Mostofa, M Sharif and SMA Khalid, 2004. Efficacy of levanid against natural gastrointestinal nematodiasis and paramphistomiasis in sheep. The Bangladesh Veterinary Journal, 21: 7073.

Juli MSB, MF Hoque, ATM Badruzzaman and HM Kawser, 2015. Bovine diseases at Dinajpur district of Bangladesh: Epidemiological status with relation to age and season. Annals of Veterinary and Animal Science, 2: 55-63.

Karim MR, MS Parvin, MZ Hossain, MT Islam and MT Hussan, 2014. A report on clinical prevalence of diseases and disorders in cattle and goats at the upazilla veterinary hospital, mohammadpur, magura. Bangl. J. Vet. Med., 12: 47-53.

Kendall SB, 1954. Fascioliasis in Pakistan. Annals of Tropical Medical Parasitology, 48: 307-313.

Kitching RP, Hutber AM and MV Thrushfield, 2005. A review of foot-and- mouth disease with special consideration for the clinical and epidemiological factors relevant to predictive modeling of disease. Vet J., 169:197-209.

Nandi S and BS Negi, 1999. Bovine Ephemeral fever. A review. Comp. Immunol. Microbiol. Infec. Dis., 22: 81-91.

Kocan KM, 1986. Development of Anaplasma marginale in ixodid ticks: coordinated development of a rickettsial organism and its tick host. In: Sauer, J. R., Hair, J. A. (Eds.), Morphology, Physiology and Behavioral Ecology of Ticks, Ellis Horwood Ltd., England, pp 472-505.

Kocan KM, J De La Fuente, EF Blouin and JC Garcia-Garcia, 2004. Anaplasmamarginale (Rickettsiales: Anaplasmataceae): recent advances in defining host-pathogen adaptations of a tick-borne rickettsia. Parasitology, 129: 285-300.

Mackerras IM, MJ Mackerras and FM Burnet, 1940. Bull. Connc. Sci. Ind. Res. Melb., 136: 1-116.

Mannan MA, MP Siddique, MZ Uddin and MM Parvez, 2009. Prevalence of foot and mouth disease (FMD) in cattle at Meghna upazila in Comilla in Bangladesh. Journal of Bangladesh Agricultural University, 7: 317 319. 
Magona JW, J Walubengo, W Olaho-Mukani, NN Jonsson, SW Welburn and MC Eisler, 2011. Spatial variation of tick abundance and seroconversion rates of indigenous cattle to Anaplasma marginale, Babesia bigemina and Theileria parva infections in Uganda. Experimental and Applied Acarology, 55: 203-213.

Mas S, MD Bargues and JG Esteban, 1999. Human fascioliasis. In: Fascioliasis, Dalton JP ED, Wallingford: CAB International, pp: 411-34.

Nath BD, Ahasan MS, Rahman MS and AKM Fazlul Huque, 2010. Prevalence and therapeutic management of bovine dermatophilosis. Bangladesh Research Publications Journal, 4: 198-207.

Okiluddin SM, 1996. Studies on fascioliasis of cattle in Kishoregonj district. M. Sc. Thesis, Department of Parasitology, Bangladesh Agricultural University, Mymensingh.

Pallab MS, SM Ullah, MM Uddin and OF Miazi, 2012. A cross sectional study of several diseases in cattle at ChandanaishUpazilla of Chittagong district. Scientific Journal of Veterinary Advances, 1: 28-32.

Rahman MA, KMKM Ali, A Rahman, 1972. Incidence of diseases of cattle in Mymensingh. Bangladesh Veterinary Journal, 6: 25-30.

Rahman MA, MA Islam, MA Rahman, AK Talukder, MS Parvin and MT Islam, 2012. Clinical diseases of ruminants recorded at the Patuakhali science and technology university veterinary clinic. Bangl. J. Vet. Med., 10: 63-73.

Rony SA, MMH Mondal, N Begum, MA Islam and S Affroze, 2010. Epidemiology of ectoparasitic infestations in cattle at Bhawal forest area, Gazipur. Bangl. J. Vet. Med., 8: $27-33$.

Samad MA, 2001. Observations of clinical diseases in ruminants at the Bangladesh Agricultural University Veterinary Clinic. Bangladesh Veterinary Journal, 35: 93-120.

Sarker S, S Talukder, MH Haque, MH Islam and SD Gupta, 2011. Epidemiological study on foot and mouth disease in cattle: prevalence and risk factor assessment in Rajshahi, Bangladesh. Wayamba Journal of Animal Science, 3: 71-73.

Shelmon E and AL Barwari, 1978. A survey on liver infections with Fasciola gigantica among slaughtered animals in Iraq. Bulletin of Endemic Diseases, Baghdad, 20: 75-82.

Speedy AW, 1992. Progress in sheep and goat research, C.A.B. International, Wallingford, Oxon, U.K, pp.179188.

Uren ME, 1989. Bovine ephemeral fever. Aust. Vet. J., 66: 233-236.

Young PL and PB Spradbrow, 1990. Clinical response of cattle to experimental infection with bovine ephemeral fever virus. Vet. Rec., 126: 86-88. 